\title{
Being a Parent of a Child With Autism From Diagnosis to the University Years
}

\author{
Alev Girli \\ Correspondence: Alev Girli, Dokuz Eylül University, Buca Faculty of Education, İzmir, Turkey. \\ Received: February 5, 2018 \\ Accepted: March 15, $2018 \quad$ Online Published: March 29, 2018 \\ doi:10.11114/jets.v6i5.3146 \\ URL: https://doi.org/10.11114/jets.v6i5.3146
}

\begin{abstract}
When literature is examined, it is seen that generally there are descriptive studies examining the effects of young children with autism in a certain age or age range on their parents' marital and family relationships as well as psychological conditions such as mourning, stress, anxiety, and depression. Longitudinal studies on the social experiences of parents of children with autism are scarce. It was observed that there was not a longitudinal study in Turkey, evaluating the emotional processes parents live through from the years when their children are diagnosed with autism until the university education, the changes they experience in family relations, the problems they encounter in their children's education process, and the emotional-social support services they receive/do not receive. This study is a qualitative study that examines the 15-16 years of experience of autistic children's parents by analyzing video interview records that were carried out using a semi-structured interview form. The results were examined under seven themes and five sub-themes, and the results that were obtained were in accordance with the literature.
\end{abstract}

Keywords: autism, parents, family relations, social experiences, future expectations

\section{Introduction}

The family system approach considers individuals as a structure within their families and considers the family within the context of society. There are sometimes changes in the family system. The roles in the family can change. For example, someone can play the role of child, sibling and caregiver at the same time. And these roles change over time, as well. In addition, the family system should be able to adapt to changing conditions as time progresses and during transition times (McGoldrick, Carter, \& Garcia-Preto, 2011). The family system theory and the research on it provide us with information on how families manage to overcome a typical turning point, such as the birth of a child. Additional risks and stress sources in a turning point should be considered. When a child with a special need is born, spouses, parents and siblings relations may experience unusually high stress periods, and relationships should be reorganized in such periods (McGoldrick et al., 2011). For example, when a child is diagnosed with autism, families have to continually accomplish many new tasks, such as understanding medical and other diagnostic information, getting help for the needs of children from specialists and services and financing these (Guralnick, 2000; Minnes, 1988).

In Lawson's (1988) family development model, couples placed in seven stages of family. Each stage is organized according to the year of marriage and the presence or absence of children. Accordingly, the 1st stage is called childless couples ( $0-2$ years of marriage); 2nd stage, childbirth (3-4 years of marriage); 3rd stage, pre-school family (5-9 years of marriage); 4th stage, the school age family (10-16 years of marriage); 5th stage, adolescent family (17-31 years of marriage); 6th stage, children's beginning to work (32-43 years of marriage) and 7th stage vacant home and post-retirement (44 years and more of marriage). At every stage of the family development model, the family system may face new tasks and some stressful problems.

In the first stage, newly married couples experience a great happiness called "marriage joy." The birth of the child is the beginning of the second period of Lawson (1988) as a new turning point in the life of the family. A child's joining the family loads new roles on the couples and requires them to change their routines (Gladding, 2007; Miyandoab, 2008). It also affects the couple lifestyles and marital relationships, the positions of members in the family and thus their individual lives, and leads to parenting stress. The birth of a normally developing child is the most important source of joy in this period. However, in cases when the child is found to have special needs, the joy of the parents leaves its place to a lot of complicated emotions such as shock, denial, anger, regret and sadness (McCabe, 2008), and parents get intensely concerned (Ciğerli, Topsever, Alvur \& Görpelioğlu, 2014). In this period, parents of the child who is 
diagnosed with autism are seen to feel stressed about the future of their children, mothers feel guilty and depressed because of their children's disability, and fathers feel rather angry. It is seen that mothers get more anxious, depressed and stressed than fathers (Hastings, Kovshoff, Brown, Ward, Espinosa \& Remington, 2005; Wong, 2005).

In the Turkish and American families with pre-school-age - the 3rd stage - autistic children, Turkish and American mothers did not differ in their parental stress levels but differed in terms of ways of coping and family functioning. It has been found that Turkish mothers use more problem-oriented ways of coping than American mothers and that Turkish mothers have higher levels of flexibility and intertwining than American mothers (Çelimli, 2009). In Podjarny's study (2007), it has been found that parents with children in the 3-6 age group with autism had lower levels of parent-child relationships and higher levels of parental stress than parents who have children with normal growth.

Rasmussen (2000) studied the reactions of families with children with autism and in the 4th Stage of schooling to this diagnosis. Through interviews, Rasmussen has examined the mourning process of the families and their positive and negative reactions from the time their suspicions about the diagnosis began. According to the results of the research, it has been found that after the family learned this diagnosis, their stress caused by the diagnosis decreased especially through the support they received from people and institutions such as doctors, educators and therapists, and that they developed positive relationships with their children. In addition, parents have stated that the time they spent together as a couple decreased. It has been observed that families have developed reactions similar to the mourning period after receiving the diagnosis, they have experienced the greatest sadness, but the families have stated that they could not think of a life without their children, even though they received this diagnosis.

Most of the studies were done with families with young children (Jokinen, 2006). For this reason, there is not much information about the influence of children at later ages/older children on the family and the problems the families experience. In their study on families with children aged 41-52 (6th Stage), Jokinen and Brown (2005) observed that families generally discussed to have positive perceptions and that their children provided positive contributors to the family. The families defined their concerns for the future; for example, who would look after their children in the future and how the families of normally developing siblings would be influenced by this situation. In previous research studies, parents reported that they received low levels of help from individuals outside their families and that more than half of the families received "almost no" practical help from their neighbors or extended family members.

Researchers have been studying psychological health for decades in the parents of those with Autism Spectrum Disorder (ASD) and are trying to identify "stress factors" associated with adverse outcomes. The results typically indicate more negative consequences for the parents of children with ASD compared to the parents of developing children or mentally handicapped children without ASD (Hartley, Seltzer, Head, \& Abbeduto, 2012; Montes \& Halterman, 2007; Sanders \& Morgan, 1997; Sivberg, 2002). Adverse effects of children with autism on their families were generally related to the severity of behavioral problems in childhood, the severity of autistic symptoms or the multitude of stress sources (Duarte, Bordin, Yazıg1, \& Mooney, 2005; Hastings, 2003; Lecavalier, Leone \& Wiltz, 2006). Some researchers generally associate negative outcomes with stressful experiences (Davis \& Carter, 2008; Ekas, Lickenbrock \& Whitman, 2010; Lecavalier et al., 2006) or mental health problems (Ekas et al., 2010; Weiss, Cappadocia, MacMullin, Viecili, \& Lunsky, 2012). Often mothers are more involved in the care and education of their children and this makes them feel exhausted (Benson, Karlof \& Siperstein 2008; Dabrowska \& Pisula, 2010).

Early studies for the families of children with special needs have begun in the 1970s in America and Europe, and in the 1980s in Turkey. It is seen that these studies are generally descriptive studies examining the effects of children with autism in a certain age or age range on their parents' family and marital relationships as well as psychological conditions such as mourning, stress, anxiety, and depression. The results show that there is a relationship between social support systems and families' stress, anxiety and psychological health in general. Accordingly, the results also show that families with better qualitative and quantitative social support systems are better at coping with these emotions (Beresford, 1994; Dabrowska \& Pisula, 2010; Dunn, Burbine, Bowers \& Tantleff-Dunn, 2001; Görgü, 2006; Hadadian, 1994; Özkan, 2002; White \& Hastings, 2004).

Longitudinal studies on the social experiences of parents of children with autism are scarce. Given the inadequacies of children with autism, the improvement of family life can be seen as a surprising fact. The studies have been cross-sectional by nature, examined the effects of the family at certain points over time, and focused on the development of problems related to a turning point and adaptations to these problems (Gray, 1994, 1998; Marcus, Kunce \& Schopler, 1997; Mesibov \& Handlan, 1997). Nevertheless, when these study results are considered compositely, it appears that this literature creates a consistent perspective on a problem, that these families experience a number of stages of adjustment to the child's autism, and that families gradually adapt to the experience of living with a child with autism. In addition, it is seen that there are many unknowns about this long process, and more research is needed (Gray, 2015; Weiss, Robinson, Fung, Tint, Chalmers \& Lunsky, 2013). 
It has been observed that there is no longitudinal study in Turkey, evaluating the emotional processes parents live through from the years when their child is diagnosed with autism until the university education, the changes they experience in family relations, the problems they encounter in their children's education processes, and the emotional-social support services they receive/do not receive. The aim of this study was to determine by means of thematic analyses of responses families gave to open-ended questions related to the characteristics of family life according to the "Lawson's (1988) family development model" the emotions they live through as parents, problems in marriage relationships and family relationships, their ways of coping with these problems, the characteristics of their social life, and their future expectations in the 15-16 year period from the date parents of children with autism learned the diagnosis to the university education years.

\section{Method}

This study was a qualitative study that longitudinally analyzed the experience of parents of autistic children using a semi-structured interview form with the analysis of video interview records.

\subsection{Sample}

The study was carried out in İzmir with a total of 8 people -5 mothers $(\mathrm{M})$ and 3 fathers $(\mathrm{F})$ who were parents of five ASD-diagnosed children and voluntarily participated in the study. All parents were university graduates, and a mother had a master's degree. The average age of the mothers was 48.8, and the average age of the fathers was 50. According to their own statements, families usually had a middle and upper-middle income level. All of the children with autism were male, and both children of one of the families. Information on the occupations and marital status of the parents is given in Table 1. Demographic information of children with ASD in Table 2.

Table 1. Demographic information of parents

\begin{tabular}{llllllrr}
\hline Subject no & Gender & Age & Job & Work & Income level & Marital status & Number of children \\
\hline M1 & F & 49 & Finance & Manager & Upper-middle & divorced & 1 \\
M2 & F & 54 & Accountant & Not working & Middle & married & 2 \\
M3 & F & 45 & Teacher & Teacher & Middle & married & 1 \\
M4 & F & 45 & Teacher & not working & Middle & married & 2 \\
M5 & F & 51 & Officer & Retired & Middle & married & 2 \\
F1 & M & 50 & Political Sciences & Working & Middle & divorced & 1 \\
F2 & M & 51 & Economist & Self-employed & Upper-middle & married & 2 \\
F3 & M & 49 & Economist & Self-employed & Upper-middle & married & 1 \\
\hline
\end{tabular}

Table 2. Demographic information of children with ASD

\begin{tabular}{lllllll}
\hline Subject no & Gender & Age & Diagnosis & Department & Grade level & Sibling status \\
\hline C1 & M & 21 & Asperger & Biomedical engineering & 1 & No \\
C2 & M & 21 & Asperger & Graphic design & 1 & Brother (typical development) \\
C3 & M & 19 & Asperger & Accounting & 1 & No \\
C4 & M & 21 & Asperger & Computer engineering & 3 & Younger brother (ASD) \\
C5 & M & 21 & Asperger & Chemical Engineering & 2 & Brother (typical development.) \\
\hline
\end{tabular}

\subsection{Data Collection Instrument}

The interview form developed by the researcher consisted of 28 questions. The interview form was evaluated by three experts at the doctoral level in terms of content and its final form was given. In the form, there were 9 questions for demographic information about parents and children. On the form, there were 19 semi-structured questions about the families' life and problems related to the family stage from the 1 st stage is called childless couples to $6^{\text {th }}$ stage in the sample went through, out of the 7 periods in the family life cycle. These 19 questions also included children's school experiences, problems, family relationships (spouses, siblings, child-mother/child-father), psychological states, emotions and future expectations.

\subsection{Procedures}

The families were interviewed through an association established by the families of children with autism in the province of Izmir, the purpose of the study was explained, and appointments were made for the families for interviews. Interviews with parents were conducted individually by the researcher. At the beginning of the interviews, the purpose of the study was explained again; they were told that a camera recording would be taken; and their verbal approvals were taken. Interviews were recorded with video. Interviewing durations ranged from 45 minutes to 1.30 hours.

\subsection{Analysis}

The parents' responses to the interview questions were analyzed using the Thematic analysis method, one of the qualitative analysis methods (Braun and Clarke, 2006). The video recordings were watched, and the answers given to 
the questions were transcribed one-to-one on a paper. The responses with common features were grouped by themes and sub-themes. Seven main themes and five sub-themes related to the education process were identified. These were: 1 . Marriage and family relationships in the period prior to the child, 2. Living as a family with a small child and those experienced during the diagnosis period, 3. Living throughout the education process and problems (special education, pre-school, primary school, high school and university sub-themes), 4. Adolescence period and problems, 5. Marriage, spouse relationships and differences from other families, 6. Psychological problems and emotional-social support, 7. Future expectations as a family.

\section{Results}

\section{Theme 1: Period prior to the child}

In this period called "newly married couple," it was observed that the parents remembered this period happily in accordance with the literature (Lawson, 1988). Three mothers and two fathers characterized the childless period of their marriages as happy and trouble free. All the parents said that they wanted to have a child very much, and that they fantasized very nice dreams. For example, with the expression that "I like children very much. At the age of 15, I started to dream for my future children. I dreamed that my child would be very useful and important to my country like Atatürk did," B2 stated the expectation of an "ideal baby" - how he was expecting his child to be. Two couples stated that they had some problems before they had children, too. They expressed that when they learned their child was "autistic," they shifted their focus on this problem and left their own conflicts aside. For example, A1 said, "We had problems before we had our children, but when our son was diagnosed with autism, we left arguing things that were about us and focused on him; we waited till he graduated from the primary school, and then we divorced."

\section{Theme 2: Family with a small child and the diagnosis process}

Parents stated that they were happy when they had children, and that they observed something that was not going well around 2 years of age (he did not look up, he was constantly in motion, he did not speak). They went to a doctor to understand what was going on. C1's father, B1, stated that "The first doctor we went to said it was autism. We did not know what it was back then. When we asked, 'What does autism mean, what can we do?' the doctor said, 'There is not much that can be done, something may be done with education, but prepare yourself for bad days." The father explained what happened after he left the doctor's office with the following: "I sat down on my knees in front of the Sevinç Pastry Shop. I do not remember. People around me have lifted me up." C2's father, B2, explained the diagnosis day with the following words: "The doctor said, 'autism.' We probably got petrified. When we came out, my wife and I asked to each other, 'What is this autism?' 18-19 years ago, autism was not known as much as it is known today." He, thus, expressed that he then understood better the first shock and confusion they had experienced.

Other parents emphasized in similar ways that they "met with something they did not know." All of them also went to other doctors and when they were going they said they thought "maybe the diagnosis was wrong." In this process, they were all shocked and confused. A3, C3's mother, went to the doctor with her parents because her husband was in another city for work. She explained the process as such: "The doctor said, 'your son is autistic.' I said, 'So what, my son won't be saying mom to me?' The doctor said, 'No, he won't be able to say; he won't be able to speak, and he may wet himself,' and then I was told that I screamed a lot. When we came out of the doctor's office, my mom said, 'Do not believe him, we can go to another doctor.'I explained the diagnosis to my husband with the doctor's words. My husband found a library and immediately began to investigate autism. Now I think I have acted like the doctor. He was alone. I was so unfair. I had my father had my mother with me." The common side of the expressions was that the diagnostic process was quite traumatic for the parents and the initial reactions were shock and unbelief.

\section{Theme 3: Problems in the education process}

\subsection{Beginning the Special Education}

All of the families started special education within 2-6 months after the diagnosis. A4 resigned from her profession, teaching, with the beginning of special education for her child. She expressed her feelings in this case with the following words: "Actually, I did a master's degree. I loved my job, too, but my son was more important. One of us had to do this. I did." A3 first got unpaid leave. When the time was up, she got back to her job. She explained how they went through this process of adaptation by saying "I felt worse when I did not work. We made a new arrangement with my husband and did not interrupt the education." A2 and A5 made arrangements for special education and care work with a caregiver and the grandmothers. A1 worked for a while, but then she quit. All of the mothers arranged all their time and routines according to their child's schedule. Daily routines in the house were arranged accordingly. During this period, questioning the diagnosis continued. A3 said, "I always thought he would go to special education, and then this would end. I always thought this would be over by the age of 6." 


\subsection{Pre-School Education Period}

B1 decided that the child was ready to start pre-school education together with the special education school. But that was not easy. He explained that with the following statements: "We changed exactly 11 kindergartens. Sometimes we told the diagnosis first and we were rejected from the beginning. Sometimes we did not say it; they noticed the situation and threw us out of the school. We did not give up, tried another one." A similar experience was expressed by another father, B2, who said, "The process to start the kindergarten was very painful. We were dismissed many times. We went to a school for 3 months, another school for 1 month. We were very demoralized, but we did not give up. Finally, we could find a good teacher." A mother, A5, explained briefly, "We had problems at first but then they accepted us." In general, the early experiences of the parents were to encounter discriminatory attitudes and to be excluded from the pre-school education, which is the first step in public education.

\subsection{The First School/Primary School Period}

All the children knew how to read when they started primary school and the families felt better because the children's level of speaking was good. A mother, A4, talked about the situation as such: "He was wandering a lot in the class. Teachers turned me over many times. When I asked a question, they turned away. I cried a lot throughout his primary school period. One teacher said to another mother, 'Their place is the school of disabled. What are we going to do with them?' And I heard that, too, and I felt very sad." C3's mother, A3, said "Although I was a teacher, too, we had a lot of difficulties. His class teacher was my friend. My son did not have any difficulty academically, but because of his obsessed behaviors, his teacher had a lot of difficulties anyhow. He would not go out in the breaks because he would think the books would fall from over the desk. He needed help to play outside. This was not easy at all."

\subsection{Middle School-High School Period}

A1, A3, A4, and A5 stated that they had less problems during the middle school. The teachers did not have any problems because there was no academic problem. Only the painting teacher of A4's son said, "This is not the place for these children." But, they had a lot of trouble with friends. A5 described the situation that her child lived in this period as "My son was excluded very much. He always wandered alone in the garden. He has never been in games." The families of $\mathrm{C} 2$ and $\mathrm{C} 3$ thought that it would be more appropriate for their children to go to vocational high school during the high school period. A2 explained how she could handle this period with the following statement: "I became the president of the school family association, so I was always at the school. I helped both the teachers and my son. When there was a problem, I solved it." The vocational high schools that the both children went to were schools heavily occupied by female students, so they did not have much trouble. Their friends supported them. A3 summarized this situation with the statement that "The vocational high school period compared to kindergarten and primary school was the most comfortable time for us."

\subsection{University Period}

When choosing a profession, $\mathrm{C} 1$ chose biomedical voluntarily. A1 explained his college years as "He has only one close friend, but no problem. These are our most trouble-free years." A mother, A4, expressed the university life of her son as follows: "C4 wanted chemistry, but it happened to be the computer engineering, and now he is just adjusting to it. He does not have any friends at school. His grades are very good." A5 said, "He stays in dormitory, because we are in another city. Even this is a great success. His grades are good. He gets along with his roommate. It makes us very happy for him to go to university." In general, parents had difficult and exhausting years, and they still continued to support their children in university. The mothers A2 and A3 actively helped in the preparation of homework and exams for $\mathrm{C} 2$ and $\mathrm{C} 3$, which went to vocational school of higher education. Adaptation procedures were being implemented for these two students. The other three students were able to do their own homework academically without any support, and their level of achievement was high. At that moment, all parents were concerned about the internship.

\section{Theme 4: Adolescence problems}

A2 stated that they did not have a lot of problems with their son during adolescence. For a few minor problems, for example, she used the following expression: "While he was in the vocational high school, he lifted girls' skirts. We got over with it. He understood when we said it was wrong, but then he developed an obsession to touch nylon socks. We had very difficult times to get over with this." A1 counted establishing a relationship with the opposite sex as the most important problem. "He says, 'I want to have a girlfriend. I lost weight. I got a driver's license. The only thing that I don't have is to have a girlfriend.' He tried a couple times, but he could not keep it going." All parents stated that "It is not too much trouble to teach body care and masturbation rules during the first years of adolescence."

\section{Theme 5: Marriage, spouse relationships and differences from other families}

B2 stated that he did not have problems with his wife because of their son: "Regarding the autism, I never asked 'Is this related to your side?' Because, back then, it was perceived as a problem with the father's side, so I did not fuss. His 
brother liked C2. He had a good relationship with him, and we did not have a problem with that, either." A mother, A3, said, "I don't remember thinking about my husband at all. There was always C3 for me. We had forgotten ourselves," indicating that they had a child-centered living and the other things were not important. A4 said, "We were different from the other families. For example, the saddest thing about me was that I quitted my job. I had the master's degree, but I left it for my child. He was more important." They usually did not tell their colleagues at the outset, except their close friends. A1 said, "Some of our old friends also stopped coming and going, and we started not to go to them; Cl was restless," emphasizing loneliness as the difference of their own family. A4 said, "There was hardly anyone to help us. Sometimes we left him with my mother and went out with my husband, but we could not do it much. That is, we were usually at home." A5 said, "Of course we are different from other families. We have had very distressing, hard times with what we have experienced. When my friends complain about their children, I contemplate by saying to myself, 'Are these really difficulties?" A father, B1, added, "We lived every year as if it were two years, so we got tired and worn out. That's why we're different from other families. We struggled a lot, but we stood up, we got the result in the end. Now we are both happy and proud."

Theme 6: Psychological-social support

A3 and B3 received professional psychological support, but there were times they received support before their child was born as well. A mother, A3, said, "Both my wife and I got support. I participated in a family training group during special education before, in this period. Sometimes I got psychological support as well." Other parents did not have any psychological support. The mothers expressed that they received support mostly from their own families and a few very close friends, and that they shared their feelings with them. The fathers expressed that they talked with and shared more with their close friends. A1, B1 and A2 and B2 met the families of other autistic children, and later they became members of a family association and became active. B1 said, "I have been in contact with parents who had autistic children like us from the beginning. I have been actively involved in the management of the association. I am still the president. We are also in contact with family associations in other cities. We take strength from each other and solve our problems. I think it provides good emotional and social support for us." Thus, he explained his situation.

\section{Theme 7: Future expectations as a family}

A4 said, "I say to myself that I wish he had a nice office, I visited it, and I got proud. I wish he could get married. But he would not be able to do it. He would not hug. He would withdraw his cheek when you try to kiss him. He would tighten up. I could not kiss him to my heart's content. He would only get to me when he got a fever. So, I don't think he will marry. I have no dreams about myself. We cannot get too far away from them. Just being able to stay together with my husband is enough." A father, B1, used the phrase "We expect him to work in the future, to win his own money, to have a good job. We don't have any expectation for ourselves." A3 said, "If he is in his own home, accepts his own situation, earns his money, and has a girlfriend, it would be enough for us. We don't have any dream for ourselves, we just dream of seeing this." Both the mothers and the fathers were still not dreaming about themselves for the future. Their greatest common dream is for their children to be independent.

\section{Discussion}

This study was carried out to investigate the experiences of parents from the period of being a newly married couple to their child's age of 2-3 years — early childhood - when their children were diagnosed with autism. The results were summarized above as seven themes and five sub-themes and discussed below under these themes.

It was seen that in the period when they were newly married couples, the families, except for one couple, generally had a time of happiness called "joy of marriage" and did not remember any problems different from the other families. The happiness the parents experienced after having their children left its place to negative feelings such as sadness and anxiety, after initially being shocked by the realization that their children had autism. Similar results are reported in studies done with parents of children with autism in the literature. For example, McCabe (2008), in a study in China, interviewed 78 parents who had children with autism and found that families initially experienced shock and denial after they learned the diagnosis. Wong (2005) investigated whether parents who learned their child's diagnosis of autism lived through a mourning process and personal development experience similar to those who lost their child and observed that mothers experienced a feeling similar to mourning. In another study, it was determined that mothers experienced more anxiety, depression and stress than fathers (Montes \& Halterman, 2011).

The families participating in this study stated that they were confronted with a problem they did not know by saying "What is autism?" as in many studies in the literature related to the diagnosis process. The families stated that they wanted to know the answer to many questions such as what the diagnosis was, what would expect their children thereafter, and whether treatment would be possible or not (Ciğerli et al., 2014). However, the parents generally stated that they could not get enough information on this issue. A mother (A3) used expressions as such that would describe the doctor's explanation of the autism as traumatic. Experts state that informing the family with a clear communication, 
in the right direction, by establishing empathy at the time of diagnosis, is very decisive in the process of adaptation of the family (Ciğerli et al., 2014).

The findings about parental experiences in the educational stages show consistency with the literature. With the diagnosis and the initiation of special education process, two mothers left their working lives and rearranged the whole day according to their child with autism. These results are, in particular, compatible with studies showing that mothers are more involved in the care and education of their children and this makes them feel exhausted (Benson et al. 2008; Dabrowska \& Pisula, 2010) and the lives of mothers are set around their children, and mothers experience intense stress, depression and sadness (McCabe, 2008). The process of starting pre-school education was very difficult for parents; they had to leave many schools and had to seek new schools again to find a school to accept their children. They expressed that they were subject to discriminatory behaviors of teachers and other families in this process. The families also stated that they had similar experiences in primary school, that they heard many sad things like "their place is the school of the handicapped" and that they were trying hard to keep their children in school. Similarly, in some studies, it has been determined that the way society approaches towards the individual with autism is negative, in the form of labeling and exclusion that focus on the diagnosis and the individual's behaviors and that families have the feeling of being discriminated (Burcu, 2007; Çopuroğlu \& Mengi, 2014).

It was observed that the children and their families who participated in this study had relatively few problems in middle school and high school years. The mothers of the two autistic adolescents, especially of those who went to the vocational high school, stated that because the schools were populated heavily by female students, their children experienced fewer problems and that they were loved by their friends and had fewer problems compared to their previous school years. The university years were called the most trouble-free educational period by all of the parents. It was observed that parents were very happy because their children have reached the top level of education that can be reached. During adolescence, the autistic children were not successful in managing relationships with the opposite sex and had negative experiences such as being exploited by their peers. The families worked with their educators in this period and managed to overcome these problems.

According to the answers given to the questions about the children with autism effect on the family, it was seen that when the families learned that their children had autism, they started to keep their daily lives within the framework of work related to their child's education and health. Two of the mothers quitted their jobs. With words like "I forgot my spouse," the couples stated that their relationship with each other was weakened. Meirsschauts, Roeyers \& Warreyn (2011) note that mothers are forced to reorganize their careers after an autistic child, and that mothers cannot maintain the care and education of autistic children if they work full time. The mothers in the present study also stated that they could not afford time for themselves and could not go out for social activities for themselves. A similar finding was found in the study of Howell, Lauderdale-Littin and Blacher (2015).

Two of the 8 parents in the sample were divorced. Although there are findings that marital adjustment is low in families with disabled children, results are contradictory. Ekas et al., (2010) stated that the divorce rates in families with children with autism are quite high like $80 \%$. Apart from close friends, the couples did not tell their surroundings at the beginning of their children's diagnosis, and some of their friends who knew them stopped coming and going. Also in Çapa's (2009) study, families stated that their relatives did not accept their children and some of them indicated that the peers of their children excluded their children. The parents stated that they were very tired, had very difficult times, were often lonely, and therefore different from many other families in many aspects. A mother and a father expressed that they received professional psychological support. Other parents did not receive professional support. Four of them contributed to the establishment of a family association and expressed that they received social and emotional support through solidarity. In the study of Weiss, Wingsiong and Lunsky (2014), it was determined that families needed more social services and more guidance. However, despite these difficulties, parents stated that they supported each other within the family. In some studies, it has been found that family members get closer to each other and provide emotional support to each other in this stressful process (Matthews, Booth, Taylor \& Martin, 2011).

All of the parents always gave answers that were related to their children to the questions about their future expectations. They expressed their dreams of their children having their own home, having a job and being able to get married. They stated that they had no dreams for themselves, they just wanted to be close to their spouses and their children. These details show that parents still think that their children are the center of their lives, and that they put themselves in the background. The parents were worried about their children's future life after themselves, just as in the study of Jokinen and Brown (2005) who studied parents in the same age group.

This study reflects the results of interviews with eight parents of five children diagnosed at the age of 2-3 and who started university education. For this reason, this limitation should be considered in the generalization of the results, and it should be taken into consideration that parents of children with severe characteristics have different experiences. 
However, in this study, the results of the themes about the pre-child period, diagnosis process, special education process and its reflections on family relationships and social and emotional support systems are generally consistent with the literature on the problems parents of children with autism have. In addition, it is seen that there are many unknowns about experiences of parents. So, there are need so many longitudinal researches.

\section{References}

Benson, P., Karlof, K. L., \& Siperstein, G. N. (2008). Maternal involvement in the education of young children with autism spectrum disorders. Autism, 12(1), 47-63. https://doi.org/10.1177/1362361307085269

Beresford, B. A. (1994). Resources and strategies: How parents cope with the care of a disabled child. Journal Child Psychology \& Psychiatry, 35(1), 171-209. https://doi.org/10.1111/j.1469-7610.1994.tb01136.x

Bolman, W. (2006). The autistic family life cycle: Family stress and divorce. In Autism Society of America's, 37th National Conference. Available at: http.//asa.confex.com/asa/2006/techprogramS (Vol. 1940).

Braun, V., \& Clarke, V. (2006). Using thematic analysis in psychology. Qualitative research in psychology, 3(2), 77-101. https://doi.org/10.1191/1478088706qp063oa

Burcu, E. (2007). Türkiye'de Özürlü Birey Olma Temel Sosyolojik Özellikleri ve Sorunları Üzerine Bir Araştırma, Hacettepe Üniversitesi Yayınları, Ankara.

Çapa, B. (2009). Zihin engelli ve otistik çocuğa sahip ailelerin toplumsal hayata katılmada yaşadıkları güçlüklerin karşılaştırllması, (Yayınlanmamış Yüksek Lisans Tezi). Marmara Üniversitesi, Eğitim Bilimleri Enstitüsü.

Çelimli, Ş. (2009). A comparative study of family functioning processes of families with a child with autism in Turkey and in the United States. (Unpublished master's thesis). Middle East Technical University Social Sciences.

Ciğerli, Ö., Topsever, P., Alvur, T. M., \& Görpelioğlu, S. (2014). Engelli çocuğu olan anne-babaların tanı anından itibaren ebeveynlik deneyimleri: Farklılığı kabullenmek. Turkish Journal of Family Medicine and Primary Care, $8(3), 75-81$.

Çopuroğlu., Y. C., \& Mengi, A: (2014). Toplumsal dışlanma ve otizm, Turkish Studies, 9(5), 607-626. https://doi.org/10.7827/TurkishStudies.6993

Dabrowska, A., \& Pisula, E. (2010). Parenting stress and coping styles in mothers and fathers of pre-school children with autism and Down syndrome. Journal of Intellectual Disability Research, 54(3), 266-280. https://doi.org/10.1111/j.1365-2788.2010.01258.x

Davis, N. O., \& Carter, A. S. (2008). Parenting stress in mothers and fathers of toddlers with autism spectrum disorders: Associations with child characteristics. Journal of autism and developmental disorders, 38(7), 1278. https://doi.org/10.1007/s10803-007-0512-z

Duarte, C. S., Bordin, I. A., Yazıgı, L., \& Mooney, J. (2005). Factors associated with stress in mothers of children with autism. Autism Society, 9(4), 416-427. https://doi.org/10.1177/1362361305056081

Dunn, M. E., Burbine, T., Bowers, C. A., \& Tantleff-Dunn, S. (2001). Moderators of stress in parents of children with autism. Community mental health journal, 37(1), 39-52. https://doi.org/10.1023/A:1026592305436

Ekas, N. V., Lickenbrock, D. M., \& Whitman, T. L. (2010). Optimism, social support, and well-being in mothers of children with autism spectrum disorder. Journal of autism and developmental disorders, 40(10), 1274-1284. https://doi.org/10.1007/s10803-010-0986-y

Gladding, S. T. (2007). Family therapy: History, theory, and practice. (4th ed.). Upper Saddle River, NJ: Prentice-Hall.

Gray, D. E. (1994). Coping with autism: Stresses and strategies. Sociology of Health \& Illness, 16(3), 275-300. https://doi.org/10.1111/1467-9566.ep11348729

Gray, D. E. (1998). Autism and the family. Springfield, IL: Charles C. Thomas.

Gray, D. E. (2015). Ten years on: a longitudinal study of families of children with autism, Journal of Intellectual \& Developmental Disability, 27(3), pp. 215-222. https://doi.org/10.1080/1366825021000008639

Guralnick, M. J. (2000). Early childhood intervention: Evolution of a system. Focus on autism and other Developmental Disabilities, 15(2), 68-79. https://doi.org/10.1177/108835760001500202

Görgü, E. (2006). 3-7 Yaş Arası Otistik Çocuğa Sahip Olan Ailelerin Alglladıkları Sosyal Destek Düzeyi ile Depresyon Düzeyleri Arasındaki İlişki. (Yayınlanmamış Yüksek Lisans Tezi). Marmara Üniversitesi. Eğitim Bilimleri Enstitüsü.

Hadadian, A. (1994). Stress and social support in fathers and mothers of young children with and without disabilities. 
Early Education and Development, 5(3), 226-235. https://doi.org/10.1207/s15566935eed0503_4

Hartley, S. L., Seltzer, M. M., Head, L., \& Abbeduto, L. (2012). Psychological well-being in fathers of adolescents and young adults with Down Syndrome, Fragile X syndrome, and autism. Family Relations, 61(2), 327-342. https://doi.org/10.1111/j.1741-3729.2011.00693.x

Hastings R. P., Kovshoff H., Brown T., Ward N. J., Espinoza F.D. \& Remington B. (2005) Coping strategies in mothers and fathers of preschool and school-age children with autism. Autism, 9(4), 377-91. https://doi.org/10.1177/1362361305056078

Hastings, R. P. (2003). Child behaviour problems and partner mental health as correlates of stress in mothers and fathers of children with autism. Journal of Intellectual Disability Research, 47(4), 231-237. https://doi.org/10.1046/j.1365-2788.2003.00485.x

Howell, E., Lauderdale-Littin, S., \& Blacher, J. (2015). Family impact of children with autism and asperger syndrome: A case for attention and intervention. Austin Journal of Autism \& Related Disabilities, 1(2), 1-9.

Jokinen, N. S. (2006). Family quality of life and older families. Journal of Policy and Practice in Intellectual Disabilities, 3(4), 246-252. https://doi.org/10.1111/j.1741-1130.2006.00086.x

Jokinen, N. S., \& Brown, R. I. (2005). Family quality of life from the perspective of older parents. Journal of Intellectual Disability Research, 49(10), 789-793. https://doi.org/10.1111/j.1365-2788.2005.00753.x

Lawson, D. M. (1988). Love attitude and marital adjustment in the family life cycle. Sociological Spectrum, 8(4), 391-406. https://doi.org/10.1080/02732173.1988.9981867

Lecavalier, L., Leone, S., \& Wiltz, J. (2006). The impact of behaviour problems on caregiver stress in young people with autism spectrum disorders. Journal of Intellectual Disability Research, 50(3), 172-183. https://doi.org/10.1111/j.1365-2788.2005.00732.x

Marcus, L., Kunce, L. J., \& Schopler, E. (1997). Working with families. In D. J. Cohen \& F. R. Volkmar (Eds), Handbook of autism and development disorders (2nd ed., pp. 631-649). New York: John Wiley.

Matthews, R. A., Booth, S. M., Taylor, C. F., \& Martin, T. (2011). A qualitative examination of the work-family interface: Parents of children with autism spectrum disorder. Journal of Vocational Behavior, 79(3), 625-639. https://doi.org/10.1016/j.jvb.2011.04.010

McCabe, H. (2008). The importance of parent-to-parent support among families of children with autism in the People's Republic of China. International Journal of Disability, Development and Education, 55(4), 303-314. https://doi.org/10.1080/10349120802489471

McGoldrick, M., Carter, B., \& Garcia, P. N. (2011). Overview: The Life Cycle in its Changing Context. The expanded family life cycle: Individual, family, and social perspectives. In "The Expanded Family Life Cycle: Individual, Family, and Social Perspectives" (4th ed., pp: 1-19).. Allyn and Bacon.

Meirsschauts, M., Roeyers, H., \& Warreyn, P. (2011). The social interactive behaviour of young children with autism spectrum disorder and their mothers. Autism, 15(1), 43-64. https://doi.org/10.1177/1362361309353911

Mesibov, G. B., \& Handlan, S. (1997). “Adolescents and adults with autism”. In Cohen, D. J. and Volkmar, F. R. (Eds) Handbook of autism and pervasive developmental disorders, (2nd ed., pp: 309-322). New York: John Wiley \& Sons.

Minnes, P. M. (1988). Family resources and stress associated with having a mentally retarded child. American Journal on Mental Retardation, 93(2), 184-192.

Miyandoab, H. S. (2008). Zihinsel engelli kardeşi olan ve zihinsel engelli kardeşi olmayan 7-13 yaş grubu çocukların aile resim çizimlerinin karşılaştırılması ve analizi. (Yayınlanmamış doktora tezi). Hacettepe Üniversitesi/Sağlık Bilimleri Enstitüsü, Ankara.

Montes, G., \& Halterman, J. S. (2007). Psychological functioning and coping among mothers of children with autism: A population-based study. Pediatrics, 119(5), e1040-e1046. https://doi.org/10.1542/peds.2006-2819

Montes, G., \& Halterman, J. S. (2011). The impact of child care problems on employment: Findings from a national survey of US parents. Academic pediatrics, 11(1), 80-87. https://doi.org/10.1016/j.acap.2010.11.005

Podjarny, G. (2007). Perceptions of parent-child relationships quality in parents of children with and without autism. (Unpublished master's thesis). Carleton University, Ottawa.

Rasmussen, F. R. (2000). Parental reaction to having a child diagnosed with autism. (Unpublished master's thesis). Miami University, Miami. 
Sanders, J. L., \& Morgan, S. B. (1997). Family stress and adjustment as perceived by parents of children with autism or Down syndrome: Implications for intervention. Child \& Family Behavior Therapy, 19(4), 15-32. https://doi.org/10.1300/J019v19n04_02

Sivberg, B. (2002). Family system and coping behaviors: A comparison between parents of children with autistic spectrum disorders and parents with non-autistic children. Autism, 6(4), 397-409. https://doi.org/10.1177/1362361302006004006

Weiss, J. A., Cappadocia, M. C., MacMullin, J. A., Viecili, M., \& Lunsky, Y. (2012). The impact of child problem behaviors of children with ASD on parent mental health: The mediating role of acceptance and empowerment. Autism, 16(3), 261-274. https://doi.org/10.1177/1362361311422708

Weiss, J. A., Robinson, S., Fung, S., Tint, A., Chalmers, P., \& Lunsky, Y. (2013). Family hardiness, social support, and self-efficacy in mothers of individuals with Autism Spectrum Disorders. Research in Autism Spectrum Disorders, 7(11), 1310-1317. https://doi.org/10.1016/j.rasd.2013.07.016

Weiss, J. A., Wingsiong, A., \& Lunsky, Y. (2014). Defining crisis in families of individuals with autism spectrum disorders. Autism, 18(8), 985-995. https://doi.org/10.1177/1362361313508024

White, N., \& Hastings, R. P. (2004). Social and Professional support for parents of adolescents with severe intellectual disabilities. Journal of Applied Research in Intellectual Disabilities. 17(3), 181-190. https://doi.org/10.1111/j.1468-3148.2004.00197.x

Wong, M. K. (2005). Children with autism: parental grief and personal growth. (Unpublished master's thesis). University of Houston, Houston.

Özkan, S. (2002). Examining the social support and depression levels of families with normal and disabled children. (Unpublished master thesis). Ankara University, Institute of Social Science, Ankara, Turkey.

\section{Copyrights}

Copyright for this article is retained by the author(s), with first publication rights granted to the journal.

This is an open-access article distributed under the terms and conditions of the Creative Commons Attribution license which permits unrestricted use, distribution, and reproduction in any medium, provided the original work is properly cited. 